\begin{tabular}{ccc}
\hline \hline & http://dergipark.gov.tr/anatolianbryology & Anatolian Bryology \\
& DOI: 10.26672/anatolianbryology.555763 & Anadolu Briyoloji Dergisi \\
Research Article \\
\end{tabular}

\title{
The Epiphytic Bryophyte Communities of Akyazı District (Sakarya, Turkey): A Multivariate Study of Community-Habitat Relationships
}

\author{
Mevlüt ALATAŞ*1 iD, Güray UYAR ${ }^{2}$ iD, Tülay EZER ${ }^{3,4}$ iD, Muhammet ÖREN ${ }^{5}$ iD \\ ${ }^{I}$ Munzur University, Faculty of Engineering, Department of Bioengineering, Tunceli, TURKEY \\ ${ }^{2}$ Ankara Hacı Bayram Veli University, Polatl Faculty of Science \& Arts, Department of Biology, Ankara, TURKEY \\ ${ }^{3}$ Niğde Ömer Halisdemir University, Faculty of Science \& Arts, Department of Biology, Niğde, TURKEY \\ ${ }^{4}$ Niğde Ömer Halisdemir University, Faculty of Architecture, Department of Landscape Architecture, Niğde, TURKEY \\ ${ }^{5}$ Zonguldak Bülent Ecevit University, Faculty of Science \& Arts, Department of Biology, Zonguldak, TURKEY
}

\begin{abstract}
\begin{tabular}{lll}
\hline Received: 18.04.2019 & Revised: 07.06.2019 & Accepted: 01.07.2019 \\
\hline
\end{tabular}
Abstract

In this study, epiphytic bryophyte vegetation of the Akyazı District in Sakarya Province (Turkey) was investigated. In the different vegetation periods of the year 2017, a total of 85 relevés taken from the trunks of trees and were classified by Braun-Blanquet method and regulated by using Detrended Correspondence Analysis (DECORANA) and Two-Way Indicator Species Analysis (TWINSPAN). TWINSPAN classification technique produced two main vegetation groups include eight clusters at the third level. The results of DECORANA indicated that the distribution patterns of epiphytic communities change from xeric to mesic and along the lower base and upper zones. The most important ecological factor for the epiphytic community differentiation in the study area, according to the ordination diagram, is humidity of the epiphytic habitats. Consequently, six epiphytic bryophyte associations and two subassociations were determined in the present paper. Among them; Orthotrichetum pallentis for the second time and Pterigynandretum filiformis -leucodontetosum sciuroidis were recorded for the first time in Turkey. Moreover, Orthotrichetum pallentis - isothecietosum alopecuroidis subass. nova was described as a new epiphytic association from the Akyazı District of Sakarya Province. Floristic and ecological characteristics such as; (humidity, light, acidity) of these new syntaxa are given with detailed descriptions.
\end{abstract}

Key words: Association, Bryophyte, DECORANA, Epiphytic, TWINSPAN, Turkey,

\section{Akyazı İlçesi'nin (Sakarya, Türkiye) Epifitik Briyofit Toplulukları: Topluluk-Habitat İlişkilerinin Çok Değişkenli Bir Çalışması}

$\ddot{O} z$

Bu çalışmada, Sakarya ili, Akyazı ilçesinin (Türkiye) epifitik briyofit vejetasyonu araştırılmıştır. 2017 yılının farklı vejetasyon dönemlerinde, ağaç gövdelerinden alınan toplam 85 örneklik alan, Braun-Blanquet metodu-kullanılarak sınıflandırılmış, Detrended Correspondence Analysis (DECORANA) ve Two-Way Indicator Species Analysis (TWINSPAN) kullanılarak da düzenlenmiştir. TWINSPAN sınıflandırma tekniği, üçüncü seviyede sekiz kümeyi içeren iki ana vejetasyon grubu üretmiştir. DECORANA sonuçları, epifitik toplulukların dağılım modellerinin, kurakçıldan nemliye taban ve üst bölgeler boyunca değiştiğini göstermiştir. Çalışma alanındaki epifitik topluluk farklılaşması için en önemli ekolojik faktör, ordinasyon diyagramına göre, epifitik habitatların nemidir. Sonuç olarak, yapılan bu çalışmada altı epifitik briyofit birliği ve iki alt birlik tespit edilmiştir. Bunlar arasından; Orthotrichetum pallentis Türkiye'den ikinci kez, Pterigynandretum filiformis -leucodontetosum sciuroidis ise Türkiye'den ilk kez kaydedilmiştir. Dahası, Orthotrichetum pallentis - isothecietosum alopecuroidis subass. nova, Sakarya ilinin Akyazı ilçesi'nden yeni bir epifitik altbirlik olarak tanımlanmıştır. Bu sintaksonların; nem, 1şık, asidite gibi ekolojik ve floristik karakteristikleri detaylı açıklamalarıyla birlikte verilmiştir.

Anahtar kelimeler: Birlik, Briyofit, DECORANA, Epifitik, TWINSPAN, Türkiye.

Corresponding author: mevlutalatas@hotmail.com

(C) 2019 All rights reserved / Tüm haklarl saklıdır.

To cite this article: Alataş M. Uyar G. Ezer T. Ören M. 2019. The Epiphytic Bryophyte Communities of Akyazı District (Sakarya, Turkey): A Multivariate Study of Community-Habitat Relationships. Anatolian Bryology. 5:2,85-99 (c) (1) () This work is licensed under a Creative Commons Attribution-NonCommercial 4.0 International License. 


\section{Introduction}

Bryophytes are classified under Bryobiotina subkingdom in Plantae consist of mosses, hornworts and liverworts (Glime, 2009). They are groups of green plants that occupy a position between the thallophytes (Algae) and the vascular cryptogams (Pteridophytes). Moreover, bryophytes are the first land plants or nonvascular land plants. Nevertheless, nothing definite is known about the origin of Bryophytes because of the very little fossil record. Evidence support that Bryophytes are evolved from Algae. During the process of origin, they developed certain adaptations to land habit. Today, they are cosmopolitan in distribution and are found growing both in the temperate and tropical regions of the world. Moreover, bryophytes grow densely in moist and shady places and form thick carpets or mats on damp soils, rocks, the bark of trees especially during the rainy season. At the same time, when habitat diversity increases, it also becomes possible for diverse plant taxa to emerge, including bryophytes, along with the development of ecologically specialised plant communities. As it is known, phytosociology is a portion of vegetation science which interested in current plant communities. Its main aims are the delimitation and characterization of vegetation types based on the complete floristic composition. In addition, it tries to explain in the plant world diversity by establishing close links with science branches such as; climate, soil, geomorphology and ecology (Kılınç, 2011).

There are a few studies on epiphytic bryophyte communities in the Turkey (Kürschner et al., 2006; 2012; Düzenli et al., 2009; Ezer, 2017; Alataş, 2018; Alataş et al., 2019a,b,c). In accordance with the results of the studies conducted regarding epiphytic bryophytes vegetation so far in Turkey, a total 49 syntaxa were determined. From these syntaxa, fourty two are at the level of association and subassociation, seven are at the level of community unknown the syntaxonomical category (Alataş, 2018; Alataş et al., 2019a,b,c). Despite these studies made and determined syntaxa, additional research is still needed to fully reveal the vertical distribution patterns, community structures of epiphytic bryophytes and, the bryosociologic richness of Turkey.

Therefore, it was thought that the nature forest areas in Turkey should be chosen as priority areas for bryophyte vegetation studies. That's why the Akyazı District of Sakarya Province in Turkey was selected as the study area in the present research; this area is located $32 \mathrm{~km}$ southwest of Sakarya Province in Turkey, has rich plant cover and represents a very special region for the ecology of Turkey. Moreover, any information about epiphytic bryophyte vegetation in this area has not been published.

As a result of the present paper, a total of 8 syntaxa were determined, 6 of which were association and 2 of which were sub-association. Among them, - isothecietosum alopecuroidis is a new sub-association for science. Together with these new records, the total number of epiphytic bryophytes syntaxa recorded in our country increases to 43 .

\section{Study Area}

Akyazı District of Sakarya Province is located in Marmara region of Turkey and is surrounded with the districts Hendek in the Northeast, Adapazarı in Northwest, Sapanca in the west, Karapürçek in the southwest, and Mudurnu District of Bolu Province in the Southeast. Besides, the study area is situated in A2 square, according to the grid system of Turkey which was adopted by Henderson (1961) (Figure 1). The climate of this area is similar to Marmara and the Black Sea climate. The air is humid in Sakarya and winters are usually rainy and mild while summers are hot. According to the amount of precipitation, the driest month is $41 \mathrm{~mm}$ in August and the maximum rainfall month is 103 $\mathrm{mm}$ in December. In addition, the average annual precipitation is $754 \mathrm{~mm}$ and the yearly average temperature is $13.9{ }^{\circ} \mathrm{C}$ the lowest recorded temperature is $-14.5^{\circ} \mathrm{C}$ and the highest recorded temperature is $41.8{ }^{\circ} \mathrm{C}$. As a result of these climatic syntheses; the study area has a semiarid and humid Mediterranean climate (Akman, 2011; URL, 1). Furthermore, this region seems to be in the euxine part of the Euro-Siberian phytogeographic region (Zohary, 1973). In accordance with the region's climate the study area is primarily covered with pure and mixed deciduous forest (e.g. Fagus orientalis Lipsky, Carpinus betulus L. and Rhododendron ponticum L.,) in the northern slopes and conifers and maquis vegetation (e.g. Abies nordmanniana (Steven) Spach ssp. equi-trojani (Asch. \& Sint. ex Boiss.) Coode \& Cullen, Pinus sylvestris L., Pinus nigra Arn. subsp. pallasiana (Lamb) Hulmboe, Pinus brutia Ten., Quercus infectoria Oliver, Laurus nobilis L., Buxus sempervirens L. and Prunus laurocerasus L.) in the southern slopes and higher parts of the area. 


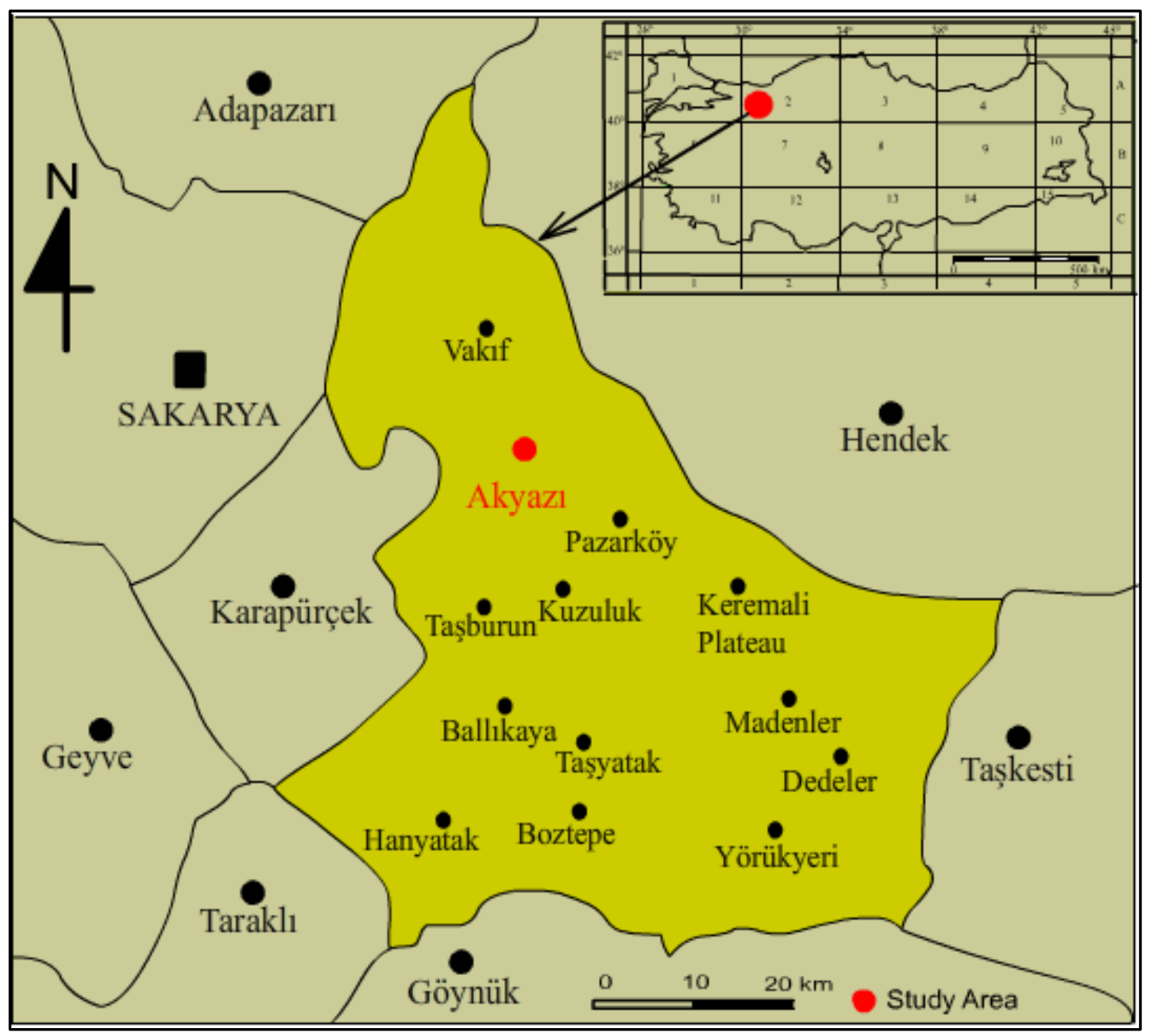

Figure 1. The Grid system of Turkey adopted by Henderson (1961) and the study area.

\section{Material and Methods}

Research materials were composed of 85 relevés were taken from the lower $(0-0,5 \mathrm{~m})$, middle and upper $(0,5-2 \mathrm{~m})$ parts of the trunks of trees which exist in the different localities of the Akyazı District with varying ecological characteristics of the year 2017 (Table 1). These relevés were selected depending on the minimal area concept. For the relevés, the abundance-coverage scale of Frey and Kürschner was used (Frey and Kürschner, 1991a, Table 2).

Relevés were evaluated in accordance with the classical method of Braun-Blanquet (1964). Multivariate analysis techniques such as Two Way Indicator Species Analysis (TWINSPAN; Hill, 1979b) and Detrended Correspondance Analysis (DECORANA; Hill, 1979a) were also used to classify and to determine the epiphytic bryophyte community structures. Plant associations were arranged by diagnostic species (Braun-Blanquet, 1964) and named according to Weber et al., (2000).

The determination of the associations in the present study was carried out via comparison with related associations in Marstaller (2006) and classified with the aid of published studies. The bryophyte specimens within the 85 relevés were identified using various flora and revision studies (Smith, 2004; Zander, 1993; Paton, 1999; Cortini Pedrotti, 2001, 2006; Heyn and Herrnstadt, 2004; Frey et al., 2006; Guerra and Cros, 2007; Casas et al., 2009; Kürschner and Frey, 2011, Plášek et al., 2015; Lara et al., 2016). 
Table 1. The list of localities.

\begin{tabular}{|c|c|c|c|c|c|c|}
\hline Localities & Number of relevés & Altitude (m) & Phorophyte & Date & \multicolumn{2}{|c|}{ GPS (N/E) } \\
\hline 1 & $1-8$ & 475 & F.o. & 20.05 .2017 & $40^{\circ} 39^{\prime} 51^{\prime \prime}$ & $30^{\circ} 40^{\prime} 04^{\prime \prime}$ \\
\hline 2 & $9-11$ & 765 & F.o. & 20.05 .2017 & $40^{\circ} 39^{\prime} 11^{\prime \prime}$ & $30^{\circ} 42^{\prime} 30^{\prime \prime}$ \\
\hline 3 & $12-18$ & 1200 & A.n.e. & 20.05 .2017 & $40^{\circ} 38^{\prime} 44^{\prime \prime}$ & $30^{\circ} 45^{\prime} 15^{\prime \prime}$ \\
\hline 4 & $19-26$ & 1520 & C.b. & 20.05 .2017 & $40^{\circ} 39^{\prime} 04^{\prime \prime}$ & $30^{\circ} 45^{\prime} 18^{\prime \prime}$ \\
\hline 5 & $27-33$ & 1168 & F.o., C.b. & 20.05 .2017 & $40^{\circ} 40^{\prime} 06^{\prime \prime}$ & $30^{\circ} 46^{\prime} 16^{\prime \prime}$ \\
\hline 6 & $34-36$ & 1080 & F.o. & 20.05 .2017 & $40^{\circ} 40^{\prime} 32^{\prime \prime}$ & $30^{\circ} 45^{\prime} 51^{\prime \prime}$ \\
\hline 7 & $37-45$ & 477 & F.o., Q.i. & 21.05 .2017 & $40^{\circ} 35^{\prime} 21^{\prime \prime}$ & $30^{\circ} 49^{\prime} 28^{\prime \prime}$ \\
\hline 8 & 46 & 1471 & F.o. & 21.05 .2017 & $40^{\circ} 38^{\prime} 40^{\prime \prime}$ & $30^{\circ} 50^{\prime} 57^{\prime \prime}$ \\
\hline 9 & $47-50$ & 1135 & F.o., A.n.e. & 22.05 .2017 & $40^{\circ} 32^{\prime} 16^{\prime \prime}$ & $30^{\circ} 40^{\prime} 56^{\prime \prime}$ \\
\hline 10 & $51-53$ & 1283 & F.o. & 22.05 .2017 & $40^{\circ} 30^{\prime} 49^{\prime \prime}$ & $30^{\circ} 39^{\prime} 47^{\prime \prime}$ \\
\hline 11 & $54-56$ & 1306 & F.o. & 22.05 .2017 & $40^{\circ} 29^{\prime} 26^{\prime \prime}$ & $30^{\circ} 41^{\prime} 10^{\prime \prime}$ \\
\hline 12 & 57 & 1355 & F.o. & 22.05 .2017 & $40^{\circ} 29^{\prime} 25^{\prime \prime}$ & $30^{\circ} 44^{\prime} 18^{\prime \prime}$ \\
\hline 13 & 58,59 & 761 & F.o., Q.i. & 22.05 .2017 & $40^{\circ} 33^{\prime} 15^{\prime \prime}$ & $30^{\circ} 46^{\prime} 51^{\prime \prime}$ \\
\hline 14 & $60-62$ & 195 & Q.i. & 24.05 .2017 & $40^{\circ} 38^{\prime} 23^{\prime \prime}$ & $30^{\circ} 38^{\prime} 52^{\prime \prime}$ \\
\hline 15 & 63 & 455 & Q.i. & 24.05 .2017 & $40^{\circ} 36^{\prime} 45^{\prime \prime}$ & $30^{\circ} 41^{\prime} 49^{\prime \prime}$ \\
\hline 16 & 64,65 & 915 & F.o. & 24.05 .2017 & $40^{\circ} 34^{\prime} 51^{\prime \prime}$ & $30^{\circ} 38^{\prime} 11^{\prime \prime}$ \\
\hline 17 & $66-70,83-85$ & 1159 & F.o. & 24.05 .2017 & $40^{\circ} 30^{\prime} 42^{\prime \prime}$ & $30^{\circ} 37^{\prime} 27^{\prime \prime}$ \\
\hline 18 & $71-77$ & 1157 & F.o. & 23.08 .2017 & $40^{\circ} 33^{\prime} 32^{\prime \prime}$ & $30^{\circ} 28^{\prime} 44^{\prime \prime}$ \\
\hline 19 & 78,79 & 1095 & F.o. & 23.08 .2017 & $40^{\circ} 34^{\prime} 08^{\prime \prime}$ & $30^{\circ} 28^{\prime} 15^{\prime \prime}$ \\
\hline 20 & 80 & 835 & F.o. & 24.08 .2017 & $40^{\circ} 35^{\prime} 36^{\prime \prime}$ & $30^{\circ} 32^{\prime} 36^{\prime \prime}$ \\
\hline 21 & 81,82 & 1121 & F.o. & 24.08 .2017 & $40^{\circ} 34^{\prime} 12^{\prime \prime}$ & $30^{\circ} 32^{\prime} 27^{\prime \prime}$ \\
\hline
\end{tabular}

Table 2. The abundance-coverage scale used for bryophytes.

\begin{tabular}{|c|l|c|c|}
\hline Scale & Abundance-coverage & Scale & Abundance-coverage \\
\hline+ & $<\% 1$ & 3 & $\% 12,1-25,0$ \\
\hline 1 & $\% 1,1-6,0$ & 4 & $\% 25,1-50,0$ \\
\hline 2 & $\% 6,1-12,0$ & 5 & $\% 50,1-100$ \\
\hline
\end{tabular}

\section{Findings}

As a result of the study; a total of eight syntaxa including six associations and two subassociations were determined within the total 85 relevés. Moreover, the phytosociological data obtained from these relevés were evaluated by multivariate statistical analyses (TWINSPAN and DECORANA). TWINSPAN classified epiphytic bryophyte vegetation into eight clusters at the third hierarchical level. The similarity structure among these groups, which corresponds well with the accepted classification is shown in the TWINSPAN dendrogram (Figure 7), thus confirming its robustness.

DECORANA (Detrended Correspondence Analysis) ordinations were also used to search for evironmental gradients that were related to species distributions within the epiphytic bryophyte communities. According to this, axis 1 of the DCA ordination was interpreted as a height (from lower base to upper zones) gradient and axis 2 as a moisture (from xeric to mesic) gradient.

After a comparison of these groups with the phytosociological literature, we suggest their syntaxonomic interpretation into two classes, Neckeretea complanatae, and Frullanio dilatatae-Leucodontetea sciuroidis. The proposed syntaxonomic scheme in accordance with Marstaller's (2006) sequence is as follows:

Class: Neckeretea complanatae Marst. 1986

Order: Neckeretalia complanatae Jez. and

Vondr. 1962

Alliance: Neckerion compalanatae Sm. and Had. ex Kl. 1948

Associations: Anomodonto viticulosiLeucodontetum sciuroidis Wisn. 1930

Pterigynandretum filiformis Hil. 1925

Subassociation: -leucodontetosum sciuroidis Grgić 1983

Class: Frullanio dilatatae-Leucodontetea sciuroidis Mohan 1978 
Order: Orthotrichetalia Had. in Kl. and Had. 1944

Alliance: Ulotion crispae Barkm. 1958

Association: Lewinskyetum affinis Alataş \& Uyar 2017

Orthotrichetum lyellii All. ex Lec. 1975

Orthotrichetum striati (Gams 1927) Marst. 1985

Orthotrichetum pallentis Ochsn. 1928

Subassociation: - isothecietosum alopecuroidis

Alataş, Ezer, Uyar \& Ören subass. nova

Among them; Orthotrichetum pallentis for the second time and Pterigynandretum filiformis leucodontetosum sciuroidis were recorded for the first time in Turkey. Moreover, Orthotrichetum pallentis -isothecietosum alopecuroidis Alataş, Ezer, Uyar \& Ören subass. nova (Ulotion crispae alliance) was described and characterized as a new epiphytic association from the Akyaz1 District of Sakarya Province (Northwest Turkey). The descriptions of these syntaxa are as follows.

\section{Results and Discussion}

4.1. Description of syntaxa:

Pterigynandretum filiformis Hil. 1925 (Table 3)

Pterigynandretum filiformis was determined with the total of 5 relevés on tree trunks between 915 1159 meters. It was wide spread on the central and southern slopes of the study area. Fagus orientalis is the most preferred tree species by the association in the study area (Table 3; Figure 2).

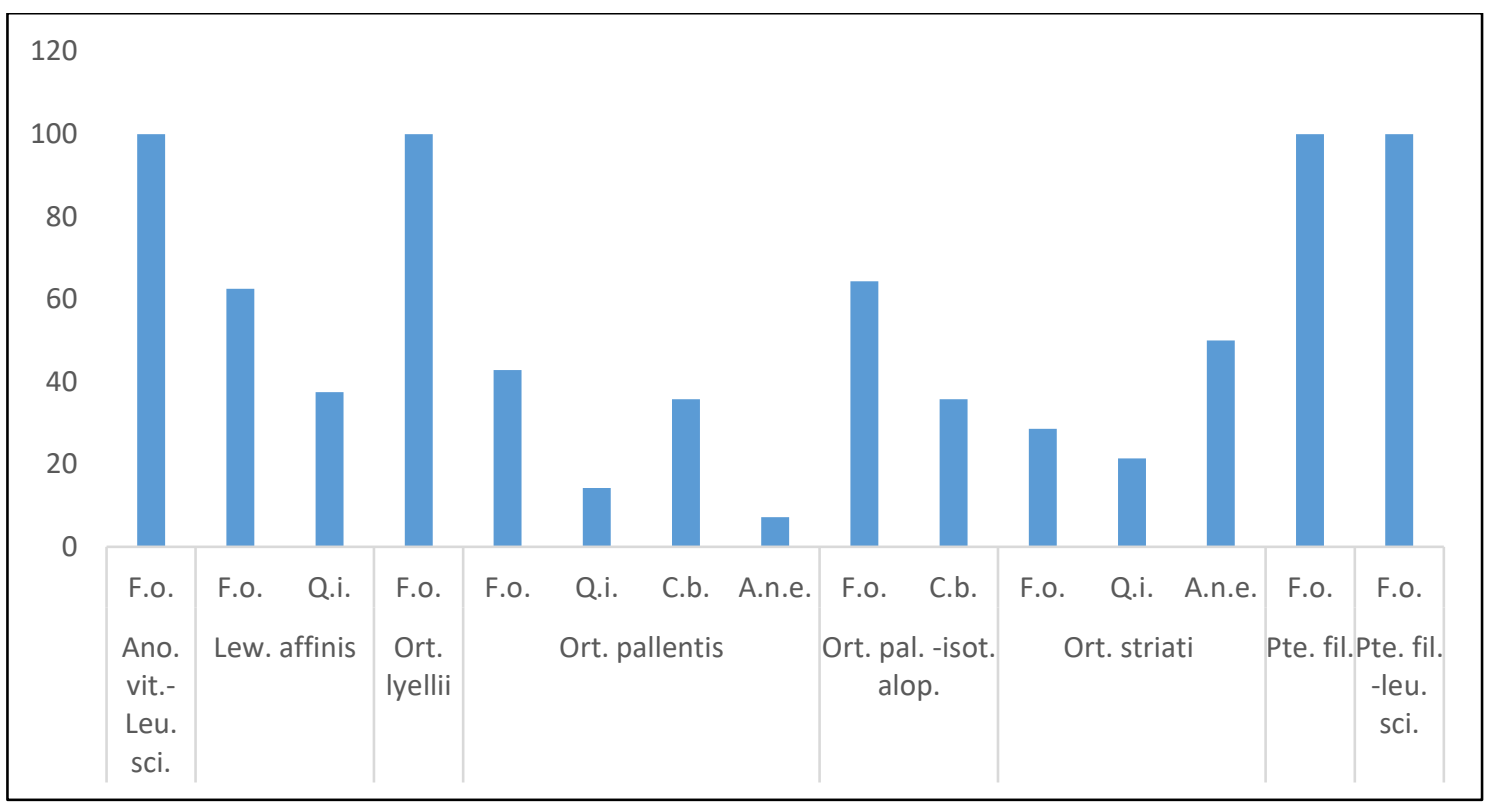

Figure 2. The tree preferences of the syntax (Ano. vit.-Leu. sci.: Anomodonto viticulosi-Leucodontetum sciuroidis, Lew. affinis: Lewinskyetum affinis, Ort. lyellii: Orthotrichetum lyellii, Ort. pallentis: Orthotrichetum pallentis, Ort. pal. -isot. alop.: Orthotrichetum pallentis -isothecietosum alopecuroidis, Ort. striati: Orthotrichetum striati, Pte. fil.: Pterigynandretum filiformis, Pte. fil. -leu. sci.: Pterigynandretum filiformis-leucodontetosum sciuroidis).

While the general cover of the taxa within the association ranges from $88 \%$ to $98 \%$, the canopy cover is $100 \%$. Taxa numbers of each relevé ranges from 5-6. A total of 13 taxa were recorded within the association. Among them 4 are liverworts, 9 are mosses (4 acrocarpous, 5 pleurocarpous).

The proximity of both liverworts and acrocarpous and pleurocarpous taxa numbers indicates that the association is a mesohygrophyte and spreads on the shady environments.
In terms of the habitat affinity of the taxa within Pterygnandretum filiformis, epiphytic taxa comprised 46\%, cortico-saxicolous taxa represented $31 \%$ and indifferent taxa made up $23 \%$ (Figure 3). When these results are compared with data from the Abant Mountains (Alataş and Uyar, 2017) where the association was first defined from our country and the Samanl Mountains (Can Gözcü et al., 2017) where it was defined for the second time; while epiphytics are the first rank in the present paper, corticosaxicolous taxa are in first rank in the other two studies. 


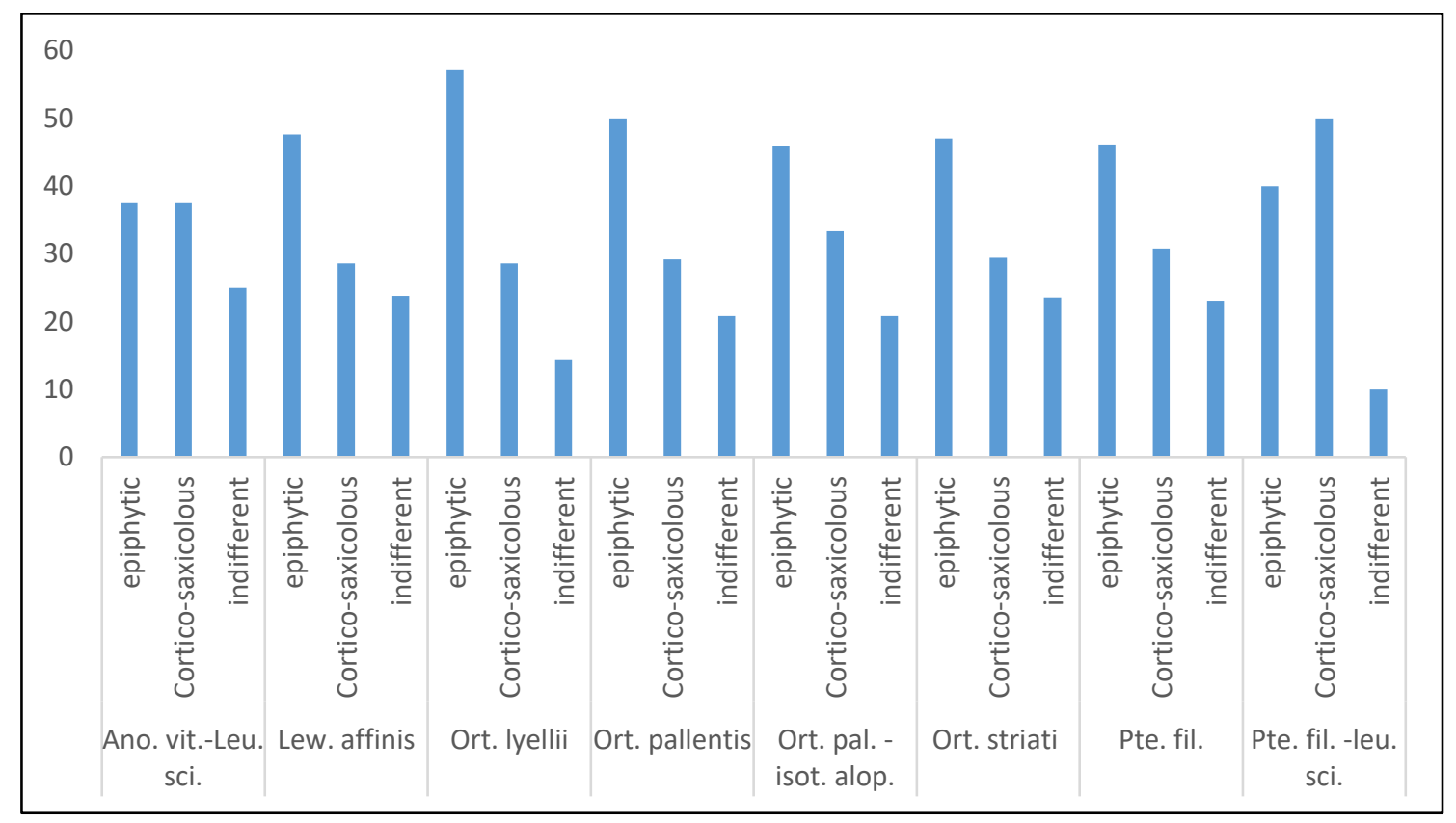

Figure 3. The habitat affinities spectrum of the species of syntaxa.

The permanency of Pterigynandrum filiforme, the diagnostic species of the association, is $100 \%$ in the relevés. The pleurocarpous Pterigynandrum filiforme generally grows on trunks as epiphytically, and also on rock surfaces as epilithically in shady, humid and alkaline habitats. Therefore, it can be said that the characteristics of the association are compatible with the ecological characteristics (acidity, humidity, light tendencities) of the taxa within the association (Figure 4,5,6).

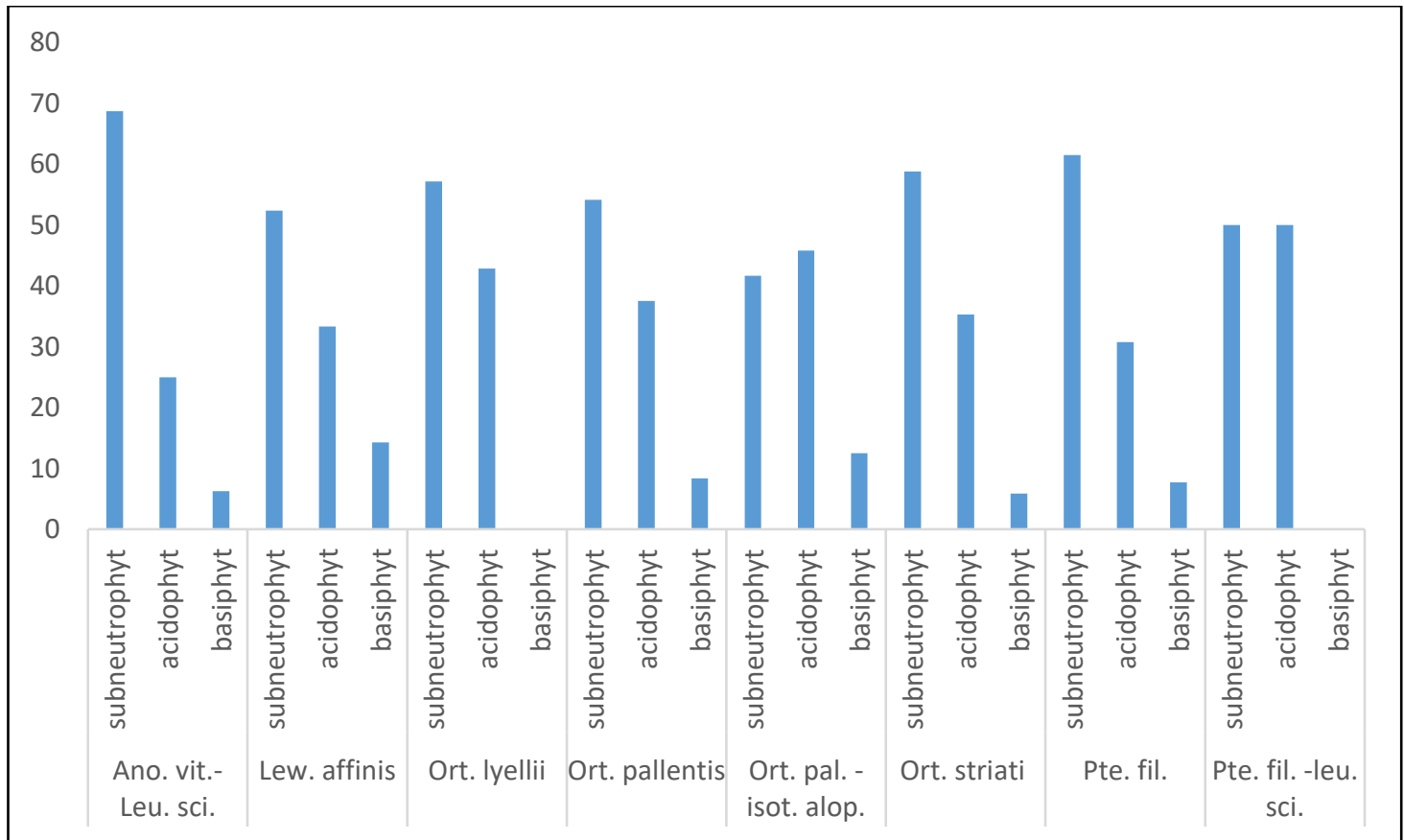

Figure 4 . The acidity spectrum of the species of syntaxa. 


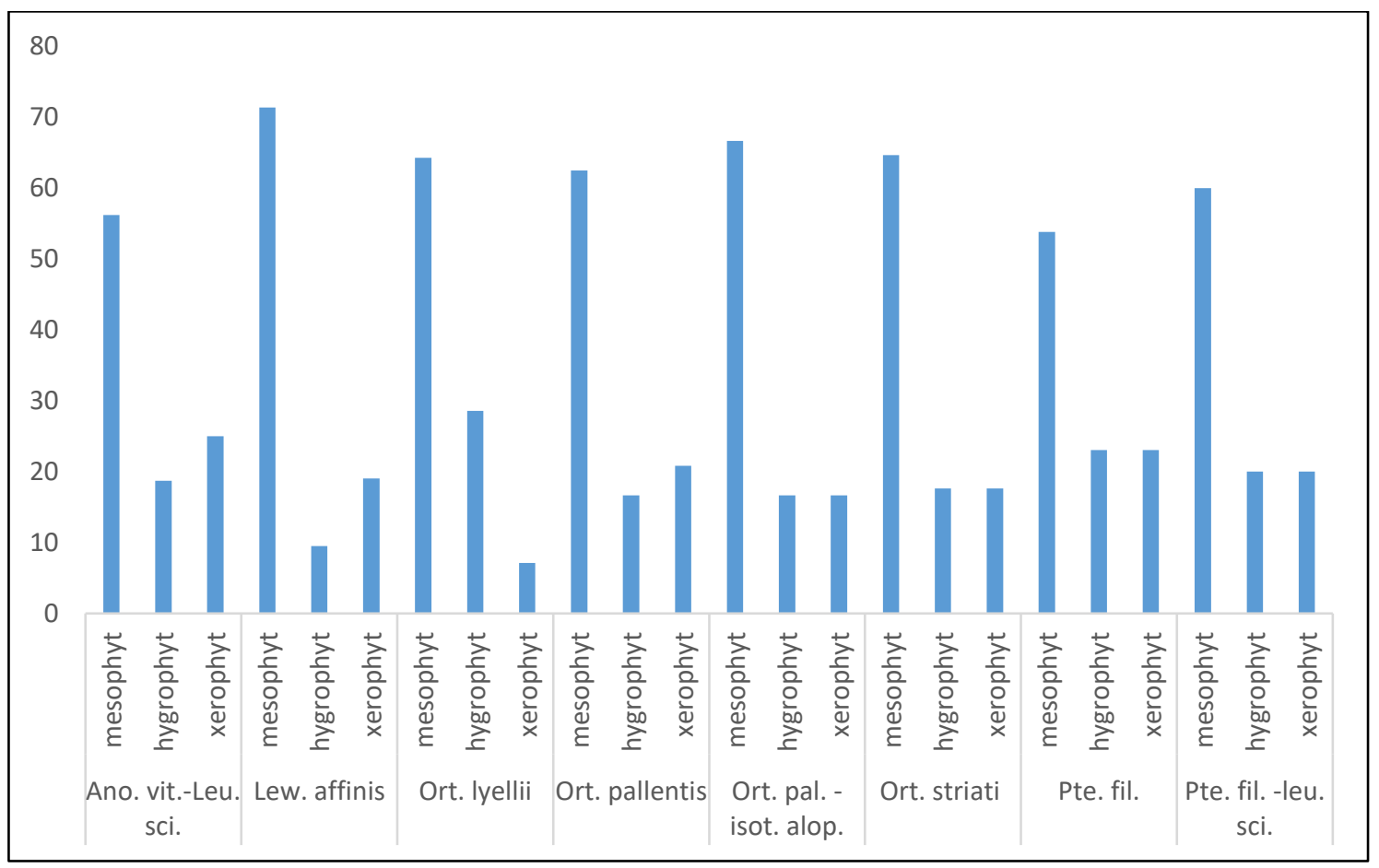

Figure 5. The humidity spectrum of the species of syntaxa.

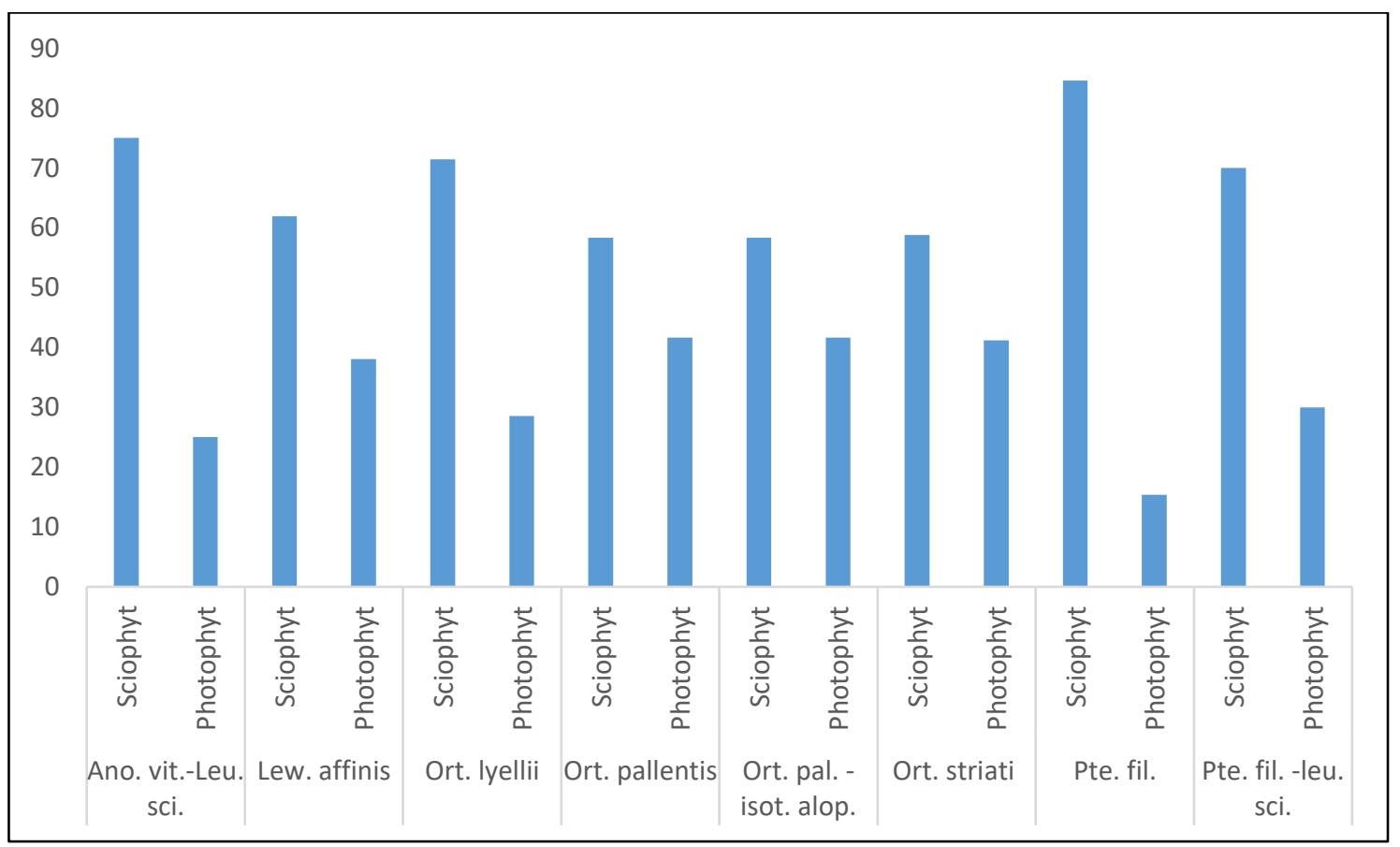

Figure 6. The light spectrum of the species of syntaxa.

Syntaxonomically, Pterigynandretum filiformis was classified in the alliance Neckerion complanatae Sm. \& Had. ex Kl. 1948, the ordo Neckeretalia complanatae Jez. \& Vondr. 1962 and, the class Neckereta complanatae Marst. 1986 due to it includes characteristic species of these upper syntaxonomic units such as Alleniella complanata, Metzgeria furcata, Radula complanata and Porella platyphylla (Table 3). 
Table 3. a: Pterigynandretum filiformis typicum Hil. 1925 and b: P.f. leucodontetosum sciuroidis

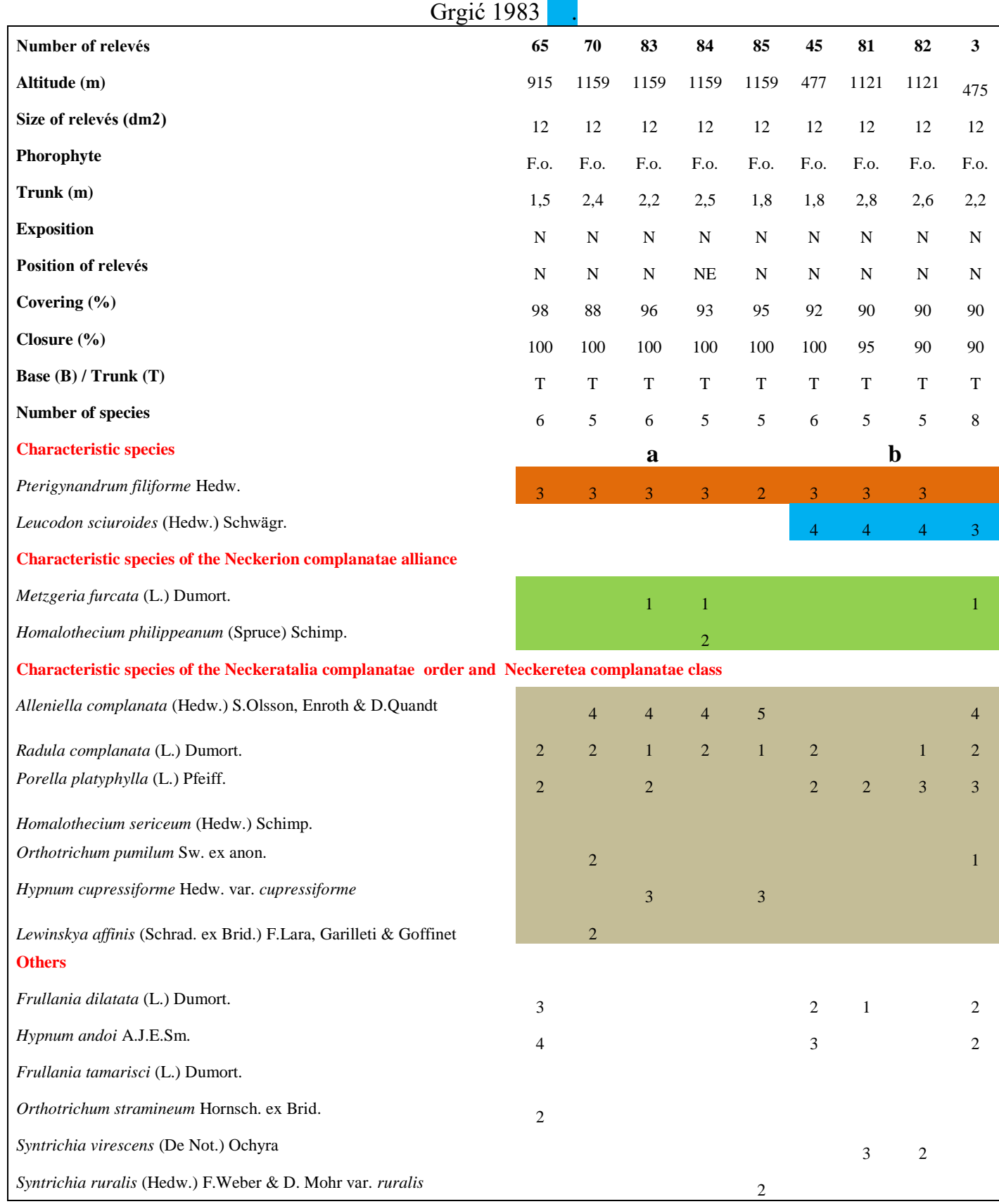

Characteristic species of the association grow both on the tree trunks as epiphytically and on rock surface as epilithically. This situation complies with the character of the association which is classified within the class Neckereta complanatae.

The association was first described by Hilitzer in 1925 as the name of Pterygnandretum filiformis, and also it was determined as an epiphytic association on the trunk on beech by Goia ve Schumacker (2004) in Romania (Marstaller, 2006; Goia ve Schumacker, 2004). Pterigynandrum filiforme, the diagnostic species of the association, is sensitive for air pollution (Dierssen, 2001). Therefore, it can be said that the association is wide-spread in the high mountain forests. In addition, the species is one of the characteristic species of Fagion, a vascular plant alliance in Europe (Dierssen, 2001).

When the determined association from the study area is compared with Marstaller (2006), Goia and Schumacker (2004), Alataş and Uyar (2017), it can be seen that it strongly overlaps in terms of characteristics of upper syntaxonomic units 
(alliance, ordo, class) and tree preference. This situation reveals the validity of the association and classification.

Pterigynandretum filiformis Hil. 1925 leucodontetosum sciuroidis Grgić 1983 (Table 3)

The epiphytic sub-association was determined with a total of 4 relevés between 475 to 1121 meters of the study area. Fagus orientalis is the most preferred tree species by the subassociation (Table 3; Figure 2).

While the general cover of the sub-association about $90 \%$, canopy cover ranges from $90 \%$ to $100 \%$. The number of taxa within the relevés ranges from 5 to 8 . The sub-association was represented by 10 taxa. Among them, 4 are liverworts and, 6 are mosses (2 acrocarpous, 4 pleurocarpous).

The permanency of mesophyte-xerophyte Leucodon sciuroides, the main characteristic species of the sub-association, within the relevés is $100 \%$ (Table 3 ). The species, generally grows as epiphytically and epilithically, spreads on acidic and semi-arid habitats in open areas.

In terms of the habitat affinity of the taxa within the sub-association, this syntaxon is characterized by cortico-saxicolous species with a large proportion $(50 \%)$. The percentage of obligate epiphytes is $40 \%$ in the sub-association (Figure 3). This situation shows that the subassociation is spreading on similar habitats with the Pterigynandretum filiformis.

An evaluation of the ecological characteristics of the taxa within the sub-association showed that the syntaxon has mesophytic characteristics, is acidic and spreads over semineutral shaded habitats (Figure 4,5,6).

Orthotrichetum pallentis Ochsn. 1928 (Table 4) Orthotrichetum pallentis was represented by a total 14 relevés which were taken from different tree trunks. It spreads on especially northern parts between 477 to 1520 meters of the study area. The most preferred tree species by the association is Fagus orientalis (Table 4; Figure 2).

The general cover of the association ranges from $85 \%$ to $98 \%$, and the canopy cover ranges from $90 \%$ to $100 \%$. The number of taxa within the relevés varied between 4 and 7 . The association comprises a total of 24 taxa. Among them, five taxa were liverworts, nineteen taxa were mosses
(10 pleurocarpous, 9 acrocarpous). The closeness of the ratio of acrocarpous and pleurocarpous taxa shows that the association has a mesophytic character and spreads on semi-neutral shade areas. The taxa, which form the association, show high compatibility with the ecological characteristics (acidity, humidity, light) of the habitats where the Orthotrichetum pallentis is spread (Figure 4,5,6).

The main characteristic species of the association is Orthotrichum pallens, which has the highest repetition and has the permanency of $100 \%$. The hygro-mesophytic species Orthotrichum pallens grows as generally epiphytic in open forest areas and semi-neutral environments.

When evaluated of the habitat tendencies of the taxa belonging to the association; the epiphytes ocurred at a rate of $50 \%$ due to high proportion of the Orthotrichaceae members within the association, while the cortico-saxicolous occurred at $29 \%$; and the rate of indifferent taxa was $21 \%$ (Figure 3 ). Therefore, can be said that the association is epiphytic.

Leucodon sciuroides, Frullania dilatata and Radula complanata which are characteristic species of the class were represented with high proportion in the Orthotrichetum pallentis. Also, characteristic species of the alliance such as Pterigynandrum filiforme, Metzgeria furcata, Hypnum andoi and Ulota crispa are found in the association. Therefore, Orthotrichetum pallentis in the present paper was classified within the Frullanio dilatatae-Leucodontetea sciuroidis Mohan 1978 and Orthotrichetalia Hadac in Klika and Hadac 1944 (Table 4).

When Orthotrichetum pallentis which is the second record for Turkey with this study, is compared with Hübschmann (1986), Baisheva (2000), Goia and Schumacker (2004), Marstaller (2006), and Alataş et al. (2017); it has been seen that in terms of floristic composition and ecological characteristics is similar. 
Table 4. a: Orthotrichetum pallentis typicum Ochsn. 1928 and b: O.p. isothecietosum alopecuroidis Alataş, Ezer, Uyar \& Ören subass. nova

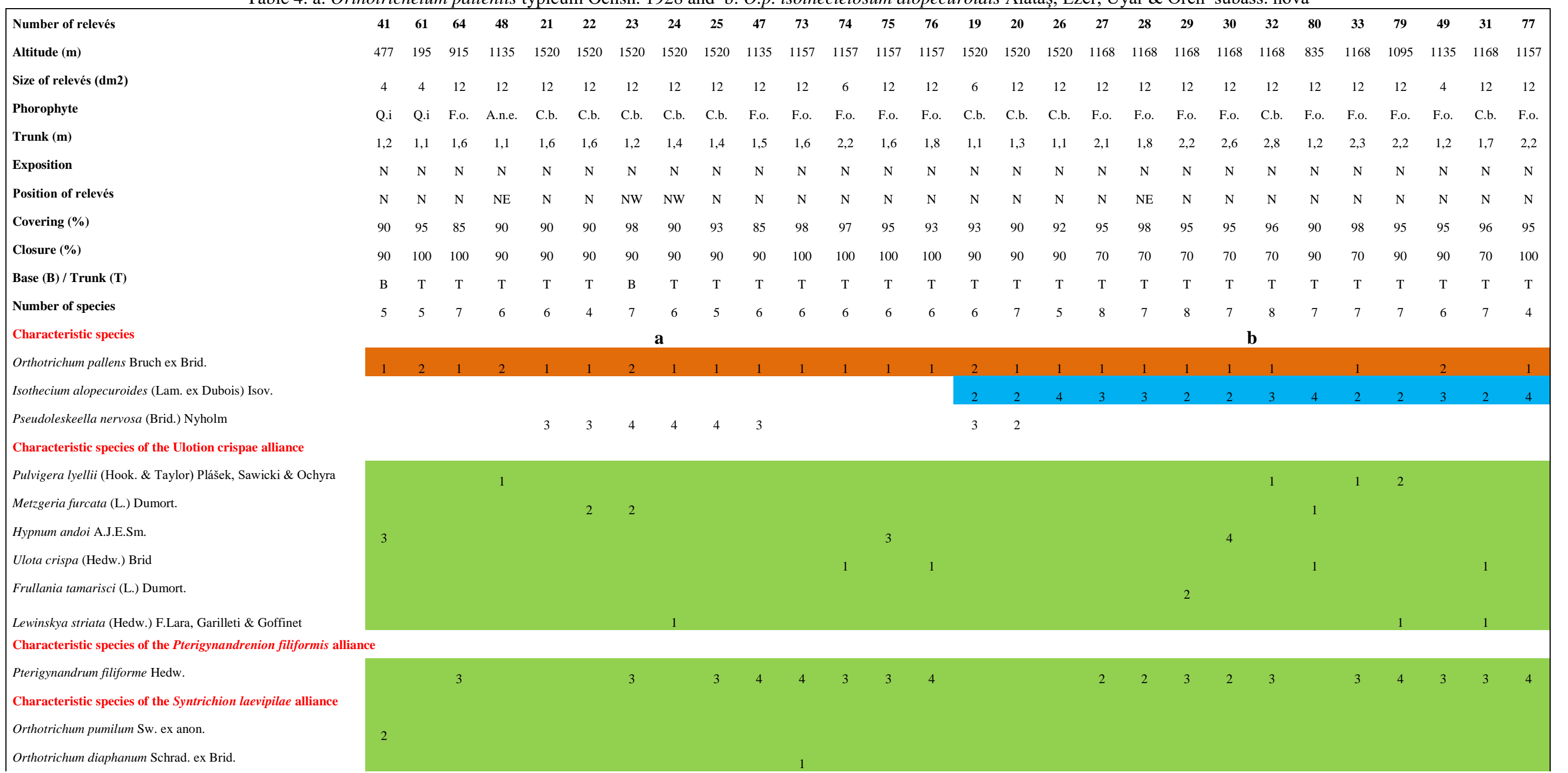


Characteristic species of the Orthotrichetalia order and Frullanio dilatatae-Leucodontetea sciuroidis class

Frullania dilatata (L.) Dumort.

Radula complanata (L.) Dumort.

Leucodon sciuroides (Hedw.) Schwägr.

Radula lindenbergiana Gottsche ex C. Hartm.

Homalothecium sericeum (Hedw.) Schimp.

Lewinskya affinis (Schrad. ex Brid.) F.Lara, Garilleti \& Goffinet

Lewinskya speciosa (Nees) F.Lara, Garilleti \& Goffinet

Others

Porella platyphylla (L.) Pfeiff.

Homalothecium philippeanum (Spruce) Schimp.

Anomodon attenuatus (Hedw.) Huebene

Antitrichia curtipendula (Hedw.) Brid.

Hypnum cupressiforme Hedw. var. resupinatum (Taylor)

Schimp

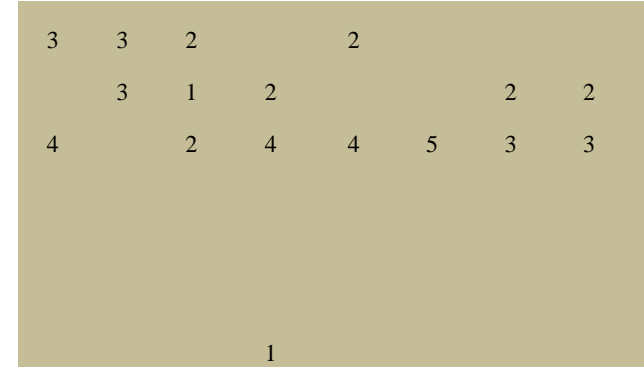

Ptychostomum moravicum (Podp.) Ros \& Mazimpaka

Hypnum cupressiforme Hedw. var. cupressiforme

Syntrichia ruralis (Hedw.) F.Weber \& D. Mohr var. ruralis

Brachytheciastrum velutinum (Hedw.) Ignatov \& Huttunen

Serpoleskea confervoides (Brid.) Kartt.

Hypnum cupressiforme Hedw. var. lacunosum Brid.

Plagiothecium succulentum (Wilson) Lindb.

2
22

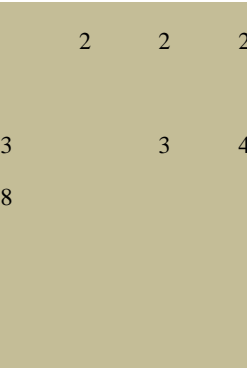

3

3

$4 \quad 4$

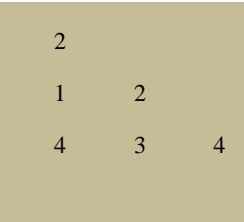

2
4

2

2
$2 \quad 2 \quad 2$

$$
2
$$

2

2

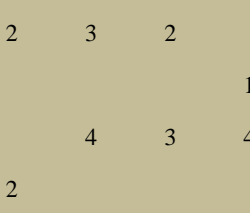

2 
Orthotrichetum pallentis Ochsn. 1928 isothecietosum alopecuroidis Alataş, Ezer, Uyar \& Ören subass. nova (Table 4)

Nomenclatural type: Table 4. relevé 32 (orig.). holotypus hoc loco: Prov. Sakarya (Turkey) Akyazı District, alt. $1168 \mathrm{~m}$ a.s.l., Fagus orientalis and Carpinus betulus forests: DSubass: Isothecium alopecuroides.

The new sub-association is represented by a total of 14 relevés taken from tree trunks between 835-1520 meters of the study area. Fagus orientalis is the most preferred tree species by the sub-association (Figure 2).

The overall cover of the sub-association ranges from $90 \%$ to $98 \%$, while the canopy cover varies between $70 \%$ and $100 \%$. The number of taxa in the relevés varies between 4 to 8 . -isothecietosum alopecuroidis is represented by a total of 24 taxa in the study area. Among them 6 are liverworts and 18 are mosses (7 acrocarpous, 11 pleurocarpous). The high number of liverworts and pleurocarpous mosses in the new syntaxon shows that the study area has very rich as humid and shady habitats.

Mesophyte Isothecium alopecuroides, which separates the sub-association from the association, is the highest recurrence taxon with $100 \%$ in the relevés (Table 4). Isothecium alopecuroides, the main diagnostic species of the new association, grows as epiphytic and epilithic on semi-neutral and shady environments.

When evaluated the habitat trends of the taxa belonging to the sub-association; the proportion of epiphytic taxa is $46 \%$ and the proportion of cortico-saxicolous taxa is $33 \%$ (Figure 3). Therefore, it can be said that the new subassociation has a mesophytic character and grows as epiphytically on tree trunks in the study area where there are acidic or sub-neutral shady habitats (Figure 4,5,6).

\subsection{Analysis of Epiphytic Bryophytes Vegetation with Multivariate Methods} TWINSPAN classified epiphytic bryophyte vegetation into two main clusters and eight subclusters at a third level according to the indicator species (Figure 7). TWINSPAN firstly separated epiphytic communities as middle and upper zone communities and, lower base communities. In the first group (A) was characterized by xerophytic syntaxa. The second TWINSPAN group (B) was characterized by mesophytic syntaxa. While all the relevés of the first group were collected from the middle and upper zones of the phorophytes, the second group was collected from the basal zone of phorophytes.

The DCA distributed the epiphytic bryophyte vegetation on axis 1 and axis 2 to eight groups according to the humidity and height (height of epiphytic habitat on phorophyte) gradient (Figure 8). Results from TWINSPAN classification also reiterated the results of the DECORANA ordination. Consequently, multivariate analysis results in this study revealed that the most important environmental factors for the epiphytic bryophyte vegetation differentiation are moisture and height of epiphytic habitats on the phorophyte.

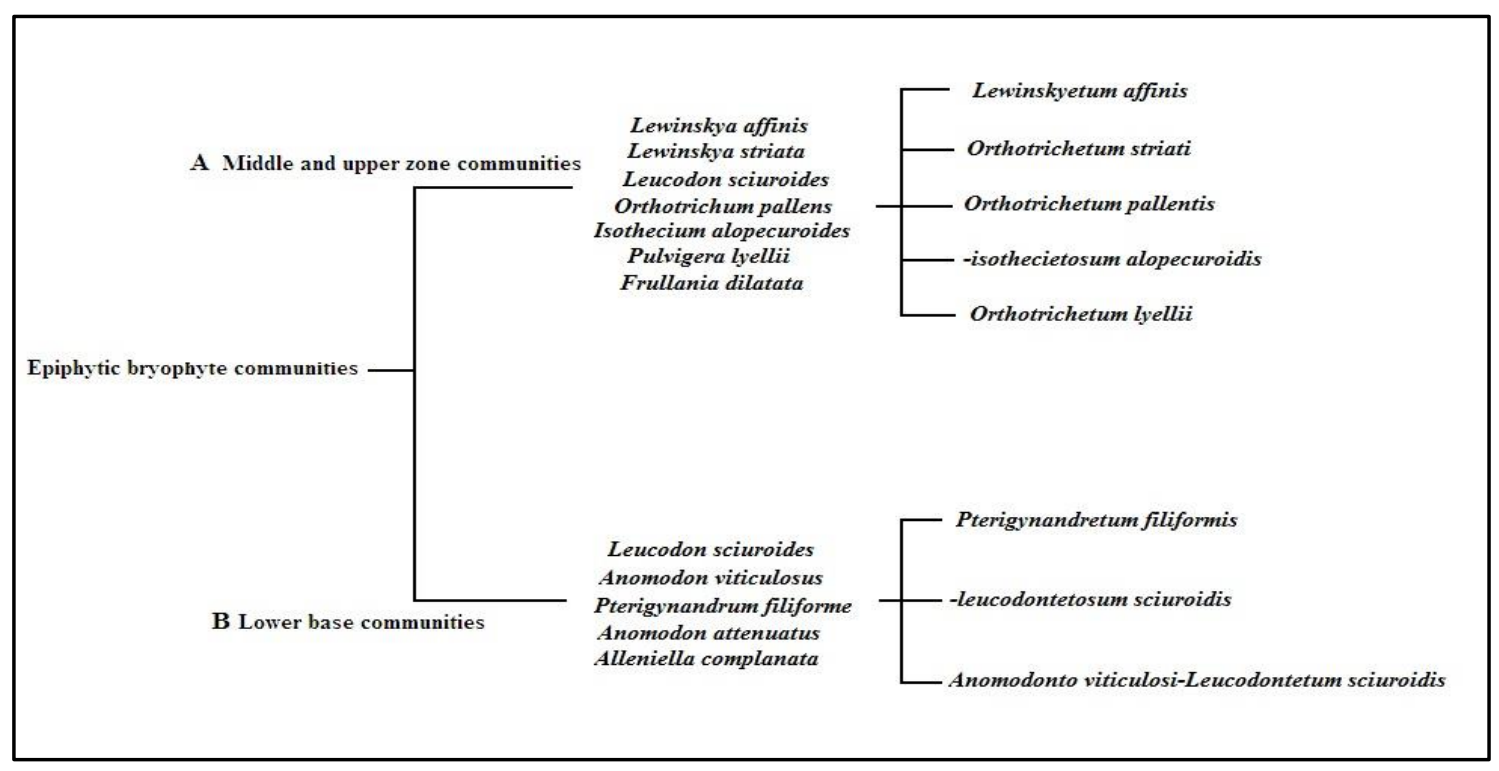

Figure 7. Dendrogram with clusters obtained by TWINSPAN. 


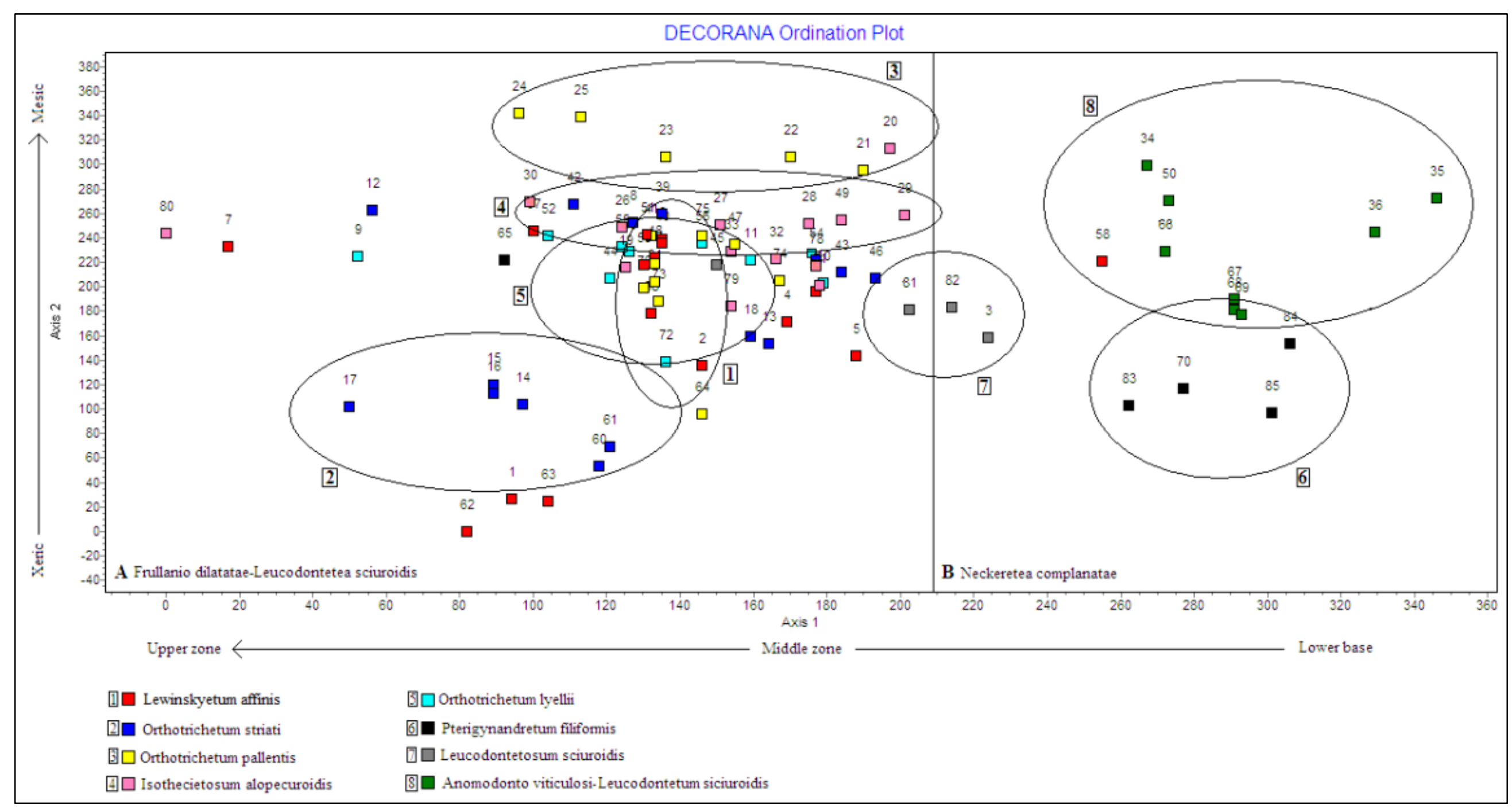

Figure 8. DCA ordination for the 85 relevés with TWINSPAN clusters. 


\section{References}

Akman Y. 2011. İklim ve Biyoiklim (Biyoiklim metodları ve Türkiye İklimleri). Palme Yayıncilık. Ankara.

Alataş M. Uyar G. 2017. A New Bryophyte Community and Three New Records for the Epiphytic Bryophyte Vegetation of Turkey. Turk J Bot. 41, 308-323.

Alataş M. Batan N. Ezer T. Uyar G. 2017. The Epiphytic Bryophyte Flora and Vegetation of Boraboy and Destek Forets (Amasya, Turkey). Pakistan J Bot. 49:5, 1779-1786.

Alataş M. 2018. Checklist of Turkish bryophyte vegetation. Botanica-Serbica. 42:2, 173 179.

Alataş M. Batan N. Ezer T. Erata H. 2019a. A new bryophyte sub-association and a new association record for Turkish bryophyte vegetation. Biological Diversity and Conservation. 12:1, 181-188.

Alataş M. Batan N. Ezer T. Erata H. 2019b. Türkiye'deki Pylaisietum polyanthae Felf. 1941 Üzerine Bir Not. Anatolian Bryology. 5:1, 8-14.

Alataş M. Batan N. Ezer T. 2019c. The Epiphytic Bryophyte Vegetation of Kamilet Valley (Artvin/Turkey). Turk J Bot. DOI: 10.3906/bot-1812-38.

Baisheva EZ. 2000. Bryophyte Vegetation of Bashkiria (South Urals). III. Epiphytic and Epixylic Communities of Western Bashkiria. Arctoa. 9, 101-104.

Barkman J.J. 1958. Phytosociology and Ecology of Cryptogamic Epiphytes.Van Gorcum. Assen.

Braun Blanquet J. 1964. Pflanzensoziologie Grundzüge der Vegetationskunde. 3. Aufl. Springer. New York.

Can Gözcü M. 2017. Samanlı Dağları'nın (Sakarya-Kocaeli-Yalova-Bursa) Briyofit Florası ve Epifitik Briyofit Vejetasyonunun Araştırılması. Niğde Ömer Halisdemir Üniversitesi Fen Bilimleri Enstitüsü. Niğde.

Casas C. Brugués M. Cros MR. Sérgio C. Infante M. 2009. Handbook of Liverworts and Hornworts of the Iberian Peninsula and the Balearic Islands. Institut $\mathrm{d}^{\prime}$ Estudis Catalans. Barcelona.

Cortini Pedrotti C. 2001. Flora dei muschi d'Italia, Sphagnopsida, Andreaopsida, Bryopsida (I parte). Antonio Delfino Editore Medicina-Scienze. Roma.

Cortini Pedrotti C. 2006. Flora dei muschi d'Italia, Bryopsida (II parte). Antonio Delfino Editore Medicina-Scienze. Roma.
Dierssen K. 2001. Distribution, ecological amplitude and phytosociological characterization of European bryophytes. Band 56. Bryophytorum Bibliotheca. Stuttgart.

Düzenli A. Ezer T. Kara R. 2009. The Anomodonto-Leucodontetum sciuroidis Wisn. 1930-an epiphytic bryophyte community new for Turkey. BotanikaSteciana. 13, 145-154.

Ezer T. 2017. Epiphytic Bryophyte Communities and Succession on Platanus orientalis Trees in Kadincik Valley (Mersin/Turkey). Pakistan Journal of Botany. 49:2, 623-630.

Frey W. Kürschner H. 1991a. Crossidium laevipilum Ther. Et.Trab. (Pottiaceae, Musci), Ein Eigenstandiges, Morphologisch und Standortökologisch Deutlich Unterscheidbares Taxon Der Saharo-Arabischen Florenregion. Criptogamie Bryol. 12, 441-450.

Frey W. Frahm JP. Fischer E. Lobin W. 2006. The Liverworts, Mosses and Ferns of Europe. Harley Books. Essex.

Garcia C. Sérgio C. Sim-Sim M. 2005. Epiphytic Bryophyte Diversity in Oak Woodlands of Centre and Northern Portugal. First analyses from a national survey. The Journal of the Hattori Botanical Laboratory. 97, 161-181.

Glime J. 2009. Bryophyte Ecology. Ebook sponsored by Michigan Technological University and the International Association of Bryologists. Website: http://www.bryoecol.mtu.edu/ [Erişim: 06 Nisan 2010].

Goia I. Schumacker R. 2004. The Study of Corticolous Bryophyte Communities from the Arieşul Mare Basin. Contribuţii Botanice. 39, 105-114.

Guerra J. Cros M. 2007. Flora Briofítica Ibérica. Vol. 1. Universidad de Murcia Sociedad Española de Briología. Murcia.

Henderson D.M. 1961. Contribution to the Bryophyte Flora of Turkey: IV. Notes from Royal Botanic Garden Edinburgh. 23, 263-278.

Heyn C.C. Herrnstadt I. 2004. The Bryophyte Flora of Israel and Adjacent Regions. The Israel Academy of Sciences and Humanities. Jerusalem.

Hill M.O. 1979a. Decorona-A Fortran Program for Detrended Correspondance Analysis and Reciprocal Averaging, Cornell University, Section of Ecology and systematic. Ithaca. 
Hill MO. 1979b. Twinspan-A Fortran Program for Arranging Multivariate Data in an Ordered Two Way Table by Classification of Individual and Attributes, Cornell University, Section of Ecology and systematic. Ithaca.

Hübschmann A. 1986. Prodromus der Moosgesellschaften Zentraleuropas Band 32. Bryophytorum Bibliotheca. Stuttgart.

Kılınç M. 2011. Bitki Sosyolojisi (Vejetasyon Bilimi). Palme Yayıncılık. Ankara.

Kürschner H. Parolly G. Erdağ, A. 2006. Life forms and life strategies of epiphytic bryophytes in Quercus vulcanica forest of Turkey. Nova Hedwigia. 82, 3-4.

Kürschner H. Frey W. 2011. Liverworts, Mosses and Hornworts of Southwest Asia. Beiheft 139. Borntraeger Verlagsbuchhandlung. Stutgart.

Lara F. Garilleti R. Goffinet B. Draper I. Medina R. Vigalondo B. Mazimpaka V. 2016. Lewinskya, a new genus to accommodate the phaneroporous and monoicous taxa of Orthotrichum (Bryophyta, Orthotrichaceae). Cryptogamie Bryologie. 37, 361-382.

Marstaller R. 2006. Syntaxonomischer Konspekt der Moosgesellschaften Europas und angrenzender Gebiete. Haussknechtia Beiheft 13. Jena.
Patiño J. Gonza'lez-Mancebo JM. Ferna'ndezPalacios JM. 2009. Epiphytic Bryophytes in Canarian Subtropical Montane Cloud Forest: The Importance of the Time Since Disturbance and Host Identity. Canadian Journal of Forest Research. 39, 48-63.

Paton J. 1999. The Liverworts Flora of the British Isles. Harley Books. Oxon.

Plášek V. Sawicki J. Ochyra R. Szczecińska M. Kulik T. 2015. New taxonomical arrangement of the traditionally conceived genera Orthotrichum and Ulota (Orthotrichaceae, Bryophyta). Acta Mus. Siles. Sci. Natur. 64, 169-174.

Smith A.J.E. 2004. The Moss Flora of Britain and Ireland. Cambridge Univ. Press. Cambridge.

URL 1. Climate Date. Website: https://tr.climatedata.org/asya/tuerkiye/sakarya/akyaz\%c4 \%b1-30620/ [06 Kasim 2017].

Weber HE. Moravec J. Theurillat JP. 2000. International Code of Phytosociological Nomenclature. Vegatation Scince. 3, 739768.

Zander R.H. 1993. Genera of The Pottiaceae: Mosses of Harsh Enviroments. Bullettin of the Buffalo Society of Naturel Sciences 32. Newyork.

Zohary M. 1973. Geobotanical Foundations of the Middle East Band 1-2. Gustave Fischer Verlag. Amsterdam. 